\title{
PRESCHOOL EDUCATION IN UKRAINE: ACHIEVEMENTS, REALITIES, PROSPECTS
}

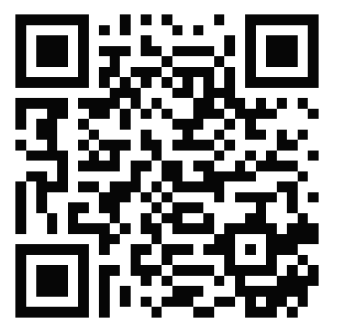

To cite this article:

\author{
Alla Bogush, Dr. Sc., Prof. \\ Head, Theory and Methods of Preschool Education Chair, \\ K. D. Ushynsky South Ukrainian National \\ Pedagogical University named after K. D. Ushynsky, \\ Odesa, Ukraine \\ svrada@i.ua \\ https://orcid.org/0000-0002-5678-5455 \\ Bogush, A. (2020). Preschool education in Ukraine: \\ achievements, realities, prospects. \\ Education: Modern Discourses, 3, 114-120. \\ https://doi.org/10.37472/2617-3107-2020-3-11
}

\begin{abstract}
The purpose of the article is to summarize the experience of the preschool education modernization in Ukraine as a sovereign state, namely in Ukraine in the $90^{\mathrm{s}}$ of the $20^{\text {th }}$ century and at the beginning of the $21^{\text {st }}$ century. The paper highlights the first steps of the preschool education development in the $90^{\text {s }}$ of the $20^{\text {th }}$ century as well as its active development phase at the beginning of the $21^{\text {st }}$ century: the development of variable programs, the Basic Component of Preschool Education, the Law of Ukraine "On Preschool Education", the First Congress of Preschool Education. Scientific achievements in the field of higher preschool education, training of scientific and pedagogical staff are considered. Perspective directions for further modernization of the preschool education sector have been identified.
\end{abstract}

Key words: achievements; Basic Component of Preschool Education; modernization; preschool education, New Ukrainian School; programs; prospects; realities; reform; Ukraine.

\section{INTRODUCTION}

The formation of the Ukrainian statehood, the development of its civil society, the integration of Ukraine into the world and European community provide an orientation primarily to the child on the principle of child-centeredness in the field of education. According to Ukrainian legislation, preschool education is a primary component of the system of continuing education. Ukraine is one of the few countries in the world where the obligatoriness of preschool education and its priority in the ideological and spiritual development and formation of the child's personality is recognized at the state level. This is the position that Ukrainian society today is objectively ready to adopt a fundamentally new understanding of the status and role of preschool education in the further development of the general education system of Ukraine. The methodology of education outlined in modern state documents (National Strategy for Education Development in Ukraine for the period 20122021, Laws of Ukraine "On Education", "On Secondary Education”, "On Preschool Education”, Basic Component of Preschool Education) gives priority to nationally conscious, socially developed, competently formed, independent, creative, proactive personality, ready for selfrealization and further life self-determination. 
It is well known that the foundations of any civil society are laid by its youngest citizens - preschool children.

\section{LITERATURE REVIEW}

It should be noted that in Ukraine in the period from 1990 until now, the research in the field of preschool education in various areas was significantly intensified: the study of the phenomena "childhood", "children's subculture", the formation of preschool children as a subject of society (L. Artemova, G. Belenka, A. Bogush, N. Gavrish, O. Kononko, V. Kuzmenko, S. Kurinna, T. Ponimanska, I. Rogalska-Yablonska, etc.), speech development of children of early and preschool age (O. Amatyeva, A. Bogush, N. Gavrish, L. Kazantseva, K. Krutiy, N. Lutsan, I. Lutsenko, N. Malinovska, Yu. Rudenko, O. Trifonova, etc.); formation of different types of preschool children's competences and competencies (T. Andryushchenko, A. Bogush, A. Goncharenko, O. Boginich, T. Stepanova, etc.), formation of professional competences of future educators of preschool children and their training in working with children (G. Belenka, A. Bogush, S. Gavrish, T. Zharovtseva, L. Zdanevich, I. Knyazheva, N. Lysenko, O. Listopad, I. Lutsenko, V. Nesterenko, etc.), child psychology (L. Kalmykova, V. Kotirlo, V. Kuzmenko, T. Pirozhenko, N. Kharchenko). The Ukrainian scientists have developed methodological and theoretical principles of teaching and educating children in preschool education establishments, created a solid foundation for further research alongside organizational and methodological innovations and reorientations in the modern system of preschool education.

\section{METHODOLOGY}

It should be noted that any social phenomenon has its own concept (conceptosphere), which develops, acts according to the relevant principles inherent to it, changes, is reformed, modernized in the context of global, interstate or state landmarks.

Today, the public and our state focus, finally, on such a capacious and archival important social phenomenon as preschool education, which during late $90^{\mathrm{s}}$ of the $20^{\text {th }}$ century transformed from "preschool education" a well-known and familiar to us term, to a new one, which does not have its own specific and clearly defined content now, which in the $21^{\text {st }}$ century prompted us to urgently develop state standards of preschool education, concepts, programs, targeted and basic, without serious reviews and discussions, sometimes trusting a small group of developers or the will of an individual leader. Unfortunately, we forget that children, future citizens of our country, stand behind all this.

Preschool education is understood as a holistic process aimed at ensuring the diverse development of the preschool child in accordance with his / her inclinations, abilities, individual psychological and physical characteristics, socio-cultural needs; formation of preschool child's moral and ethical norms, acquisition of the necessary life experience and various types of competencies.

\section{MAIN RESULTS}

Transformation of Ukraine in the $90^{\mathrm{s}}$ of the $20^{\text {th }}$ century into an independent sovereign state naturally led to a radical reform of the entire education system, a change in basic educational paradigms at all levels, including preschool, as noted in the pedagogical press, began a "crusade" to reform preschool education. 20 years have passed. Ukraine is again on the threshold of modernization of education and pedagogical science. According to methodological laws, the development of anything (object, subject, concept, industry, sphere) is its confident progress to a new higher level, but necessarily based on previous educational 
and scientific achievements in a particular field of education. We consider it necessary to characterize the progress and achievements that have taken place in Ukraine during the years of its independence, from 1991 to the present.

The first important step for Ukrainian preschool pedagogy and science, in this respect, was the possibility of reviving conceptual starting points for the separation of independent educational field of education and the upbringing of preschool children in Ukrainian kindergartens (Sofia Rusova), teaching in the native language according to the native language manual "Ridne slovo" (K. Ushynskyi) in the $19^{\text {th }}$ and $20^{\text {th }}$ centuries (Vasyl Sukhomlynskyi "I give my heart to children").

The guiding principles of the modern Ukrainian KE system were declared in the initial State National Program "Education" (Ukraine of the $21^{\text {st }}$ century), which for the first time recognized preschool education as the initial primary link of the education system and gave it a new status "preschool education" ( $1^{\text {st }}$ Congress of educators, 1992).

The program "Education" defined a strategic state task: "to develop the Basic component of preschool education and determine the criteria for assessing its quality". So, in 1992 the reform of preschool education of Ukraine started under the leadership of the Ministry of Education and Science of Ukraine, I would say, the development of a new system of preschool education began, there was a "permanent revolution" in preschool education, the "crusade" on reforming preschool education became widely used definition of "first time".

What were the achievements of preschool education in the $90^{\mathrm{s}}$ and $2000^{\mathrm{s}}$ ? First of all, standard Soviet-style programs were confiscated; developed by the author's teams on behalf of the Ministry of Education and Science of Ukraine complex programs "Baby" (Plohiy, 1992) in 1992 and "Child" in 1993 (Proskura, 1993).

It became possible to develop and implement the first partial programs for teaching children the Ukrainian language in Russian-language preschool establishments (authors A. Bogush, N. Dzyubyshyna-Melnyk, K. Stryuk) (1992-1993).

The final renewal stage of the Ukrainian system of preschool education at the end of the 20th century was aimed at the development and implementation of the first state document the State Standard - the Basic Component of Preschool Education (1998, Ph.D. in psychology N. Kononko) (Basic Component of Preschool Education, 2012). The document summarizes the rules and regulations determining the state requirements for the level of development, education and upbringing of preschoolers. These were the achievements of the $20^{\text {th }}$ century.

At the beginning of the $21^{\text {st }}$ century, a new trend of scientific search for the content of preschool education was determined. At the end of the $20^{\text {th }}$ century, the views of scientists were aimed at developing a variety of programs and personality-oriented methods of educational work with preschool children. Then in the $21^{\text {st }}$ century, the direction of experimental research of continuity and prospects in the educational work of preschool and primary education became the priority.

For the first time in the history of home preschool education, the Law of Ukraine "On Preschool Education" (2001) was adopted, which legally defined preschool education as an obligatory primary component of the system of continuing education in Ukraine. According to the Resolution of the Cabinet of Ministers of Ukraine, the education of children in preschool education institutions became compulsory at the legislative level starting with the age of 5 . In fact, an intermediate link has been singled out - preschool education, which, unfortunately, is still used today.

At the beginning of the $21^{\text {st }}$ century, there were also significant changes in the attitude to the field of "content of preschool education" in the world educational space. In October 2010, the UNESCO World Forum on Preschool Education in its Resolution stated that the foundations of education are laid in preschool age. 
For the first time in the history of the national system of preschool education, the First All-Ukrainian Congress of Preschool Workers was held in 2010 (which, so far, remained the first, possibly the last), which adopted the State Target Program for Preschool Education until 2017, which a year later canceled the educational program for older preschool children "Sure Start" (Zhebrovsky, 2012).

The Association of Preschool Workers was established in Ukraine, which today works quite actively and successfully. In Ukraine, the following profile Preschool Education journals are published: Palette of the Teacher, Bumblebee, and Educator-Methodologist of the Secondary School.

As the effect of the State Standard - the Basic Component of Preschool Education (BCPE) is limited to 10 years, a further one was issued by the Ministry of Education and Science of Ukraine to develop a new version of BCPE, which was approved for implementation in 2012, and which is still valid. The task of bringing the education and upbringing of each child as close as possible to its essence, abilities, and age features, not contrary to the nature of each child, but through his / her knowledge and development is provided by the implementation of the principle of child-centeredness, which has become extremely important.

In connection with the modernization of the primary education system according to the Concept of the New Ukrainian School (NUS), we emphasize in detail the core points of the current BCPE, which was developed taking into account the current State standards of primary education and which, in our opinion, outline some continuity between preschool and primary education in the NUS vector.

The BCPE is developed according to the leading methodological approaches as follows:

- competence-based, which provides for the formation of 21 key competencies in different educational lines (7 educational lines) as well as the State Standard of Primary Education.

According to the competence-based approach, the teacher must ultimately give the child not only a certain amount of knowledge, skills and abilities, but also form the appropriate competencies;

- activity-based approach, knowledge, skills and abilities, different types of competencies are developed in different activities; scientists recognize playing games and communicating (the child knows, can, acts) as the leading ones;

- person(ality)-oriented approach, focus on the child's personality (“Child's speech", "Child in the environment", "Child in society", etc.);

- the invariant and variable components of the BCPE were defined; the variable component allowed educators to choose other semantic lines independently. In the BCPE, the final result of development, training and education of the leaver of a preschool education institution is the formation of the holistic personal quality - preschool maturity - which consists in the child's social and psychological readiness for a new social position "schoolboy / schoolgirl", "student". The tasks of primary school are to form "school maturity" of children.

Thus, this part of the article presents the achievements of preschool education of the first educational level - preschool education institutions. If we talk about preschool education as a component of the general education system of Ukraine in its continuity, we must mention the achievements of higher education in the preschool industry, without the effectiveness of which there would be no achievements in its first link. Achievements of the preschool education sector during the $90^{\text {s }}$ of the $19^{\text {th }}$ century $-20^{\text {s }}$ of the $21^{\text {st }}$ century, will not be sufficiently understood, if we do not mention the scientific and higher branches of preschool education in Ukraine.

I will note that until 1991, there was no scientific specialization in Ukraine or in the CIS countries - preschool education. The defended dissertations specialized in 01 - Theory and History of Pedagogy on the subject of Preschool Pedagogy could be counted up to 10 titles. There was no doctor of science in Preschool Pedagogy or Child Psychology. 
Today, Ukraine has a sufficient number of more than 20 doctors of Pedagogical Sciences ( 3 of them are doctors of Psychological Sciences in Child Psychology), who have quite successful scientific schools, uniting more than a hundred active, productive candidates of Pedagogical Sciences. For the first time in Ukraine, educational and methodological support for each content line of the BCPE, textbooks, series of paintings for each age group, albums, notebooks for children, textbooks for free education filled with Ukrainian-national content have been developed to help educators.

It may look like a report of the Ukrainian preschool education, all its parts. Instead, we must not forget about it, because there was an extremely important multifaceted work on the modernization of preschool education, which could not be successful without the participation of the Government, Ministry of Education and Science of Ukraine, the National Academy of Educational Sciences (NAES), in particular its President V. Kremen (NAES branches, institutes and their directors). We should be proud of that, these are our achievements, our realities.

To move to the perspective modernization of preschool education in Ukraine, first of all, we note that today further modernization is slowing down, which we need to categorically abandon. In my opinion, these are the following positions: to abandon the sometimes distorted understanding of the concept "continuity between preschool and primary education" as teaching children narrow subject knowledge that duplicates schooling, it not only reduces children's interest in learning, but also does harm to their health. Even today, for teachers who have not moved to work in private institutions of higher education according to the NUS Concept, continuity is the presence of a certain amount of subject knowledge, skills and abilities which a child acquires.

For educators of preschool institutions, it is, first of all (and always was), care, so that the child could feel comfortable; they should preserve a unique leading activity of children of preschool age - the game, with its gradual complication and lytic transition to a new more difficult educational activity in elementary school.

I will note that this aspect is laid down in the NUS Concept and implemented in experimental schools as an adaptive-game cycle of teaching children in 1 st and $2^{\text {nd }}$ grades.

The requirement of the Ministry of Education and Science of Ukraine to develop the Concept for the Development of Early and Preschool Children, the draft of which has already been developed, is quite natural in today's challenges. In my opinion, it would be appropriate to develop a concept of modernization of kindergartens, which would cover all units of the general system of preschool education: from prenatal, perinatal, early and preschool childhood with a focus on inclusive preschool education. It includes the parental responsibility for child rearing, as well as the training of a new generation of future pedagogical specialists - specialists of preschool education (junior specialists (governors), junior bachelors, bachelors and masters - managers of preschool education and masters-teachers, masters-scientists, researchers in the field of preschool and primary education, taking into account the inclusive component in the training of future specialists in preschool education, the development of special courses on the interaction of future educators and teachers of the 1st grade.

One can ensure continuity between preschool and primary education and successfully implement it if we:

- adhere to general approaches to the organization of the educational process in both levels of education: competence, integrated, personality-oriented and activity;

- adhere to the general principles of building programs and methodological support of primary education, taking into account the previous period of development, education and upbringing of the child in the child;

- eliminate the need for common approaches to training and elaborate them in compliance with the state standards of both levels and the content of training. 
To do this, all issues of pre-school and post-secondary education must be considered together, all scientific and practical conferences on primary education must have a section on pre-school education, and all meetings at the Ministry of Education and Science of Ukraine must be attended by specialists in preschool education.

In my opinion, in the vector of the NUS Concept there is a need to develop and implement the Concept of preschool education for 6-year-old children.

In 2022, 10 years of the current BCPE will pass, so it is time to prepare a new version of the Basic Component of Preschool Education. Regarding the methodological platform of the new edition of $\mathrm{BCPE}$, it is necessary to continue using the competence-based approach, which is a priority in all areas of education in the global dimension, as well as the person-oriented, activity-based, and communicative ones, which corresponds to the psychological nature of the child.

At the same time, in compliance with the content of the NUS Concept, it is expedient to provide for the integrated and environmental approaches. Why? The results of the international study of the quality of education PISA - 2018 showed the need to implement an environmental approach, the organization of the developmental environment on the model of sustainable development of education and the formation of preschool children's holistic national picture of the world and preschoolers' awareness of socio-cultural and educational phenomena, etc.).

Thus, the successful reform and modernization of the preschool education system at the present stage should take into account all the positive achievements of our Ukrainian preschool education system, of course with a focus on the main vectors of the NUS Concept. However, primary school reform cannot be successful without taking into account the achievements of the national Ukrainian preschool education system.

\section{CONCLUSIONS}

The historical vector of formation and development of preschool education in Ukraine (from K. Ushynskyi and S. Rusova to V. Sukhomlynskyi), the transformation of preschool education into a holistic modern system of preschool education are considered. The directions of developing and reforming preschool education in Ukraine $\left(90^{\mathrm{s}}\right.$ of the $20^{\text {th }}$ century - the beginning of the $21^{\text {st }}$ century) are highlighted, perspective vectors of further modernization of the integral system of preschool education as a component of the general system of education of Ukraine are positioned.

\section{REFERENCES}

Basic Component of Preschool Education. (2012). Preschool education, 7, 4-24

Bogush, A.M. (2003a). Modernizatsiia doshkilnoi osvity v konteksti Natsionalnoi doktryny yii rozvytku [Modernization of preschool education in the context of the National Doctrine of its development]. Visnyk Hlukhivskoho derzh. ped. un-tu. Pedahohichni nauky, 2, 9-12

Bogush, A.M. (2003b). Tsinnisni priorytety doshkilnoho dytynstva. [Value priorities of preschool childhood]. In Tsinnisni priorytety osvity u 21 st. (Vol. 1, pp. 78-82) [Value priorities of education in the 21 century]. Luhansk: APN Ukrainy, Mizhnarodna akademia pedahohychnoi osvity, Luhanskyi natsionalnyi pedahohychnyi universytet im. T. Shevchenka

Bogush, A.M. (2011). Peredshkilna osvita: realii sohodennia [Preschool education: the realities of today]. Pedahohichni nauky Khersonskoho derzhavnoho pedahohichnoho universytetu, $58, I, 34-38$

Bogush, A.M. (2013). Movlennievyi komponent doshkilnoi osvity. Prohrama i navchalno- 
metodychnyi posibnyk [Speech component of preschool education. Program and training manual]. Kharkiv

Bogush, A.M. (2014). Ukrainske doshkillia : zdobutky i perspektyvy. Bibliohrafichnyi pokazhchyk. (pp. 203-216) [Ukrainian preschool: achievements and prospects. Bibliographic index]. Odesa: Feniks

Bogush, A.M. (Sc. supervisor). (2014). Oberih. Prohrama rozvytku ditei vid prenatalnoho periodu do trokh rokiv [Amulet: Program of development of children from the prenatal period to three years]. Ternopil: Mandrivets

Bogush, A.M. (Sc. supervisor). (2015). Svit dytynstva. Kompleksna osvitnia prohrama dlia doshkilnykh navchalnykh zakladiv [The world of childhood. Comprehensive educational program for preschool educational institutions]. Ternopil: Mandrivets

Pirozhenko, T. (Sc. supervisor). (2017). Osvitnia prohrama «Vpevnenyi start» dlia ditei starshoho doshkilnoho viku. Prohrama rozvytku ditei starshoho doshkilnoho viku ["Sure Start" for older preschool children. Program of development of children of senior preschool age] (scientific supervisor). Kyiv: Ukrainska akademiia dytynstva

Plohiy, Z. (Sc. supervisor). (1999). Maliatko. Prohrama vykhovannia ditei doshkilnoho viku [Baby. Preschool education program]. Kyiv

Proskura, O. (Sc. supervisor). (1993). Dytyna. Prohrama vykhovannia i navchannia ditei doshkilnoho viku [Child. Program of education and training of preschool children]. Kyiv: «Osvita»

Zakon Ukrainy "Pro doshkilnu osvitu". (2001). [Law of Ukraine "On Preschool Education"]. Kyiv: Doshkilne vykhovannia

Zhebrovsky, B. (2012). Prohrama rozvytku ditei starshoho doshkilnoho viku «Vpevnenyi start» [Program of development of children of senior preschool age "Sure start"]. Ternopil: Mandrivets 